\title{
Perspectives on Vigilantism in the Republic of Zimbabwe
}

\author{
Martin Maunga \\ Lecturer: Department of Intelligence and Security Studies, Bindura University of Science Education \\ Bindura, Zimbabwe; Email: mmmaunga@gmail.com \\ Ishmael Mugari \\ Lecturer: Department of Intelligence and Security Studies, Bindura University of Science Education \\ Bindura, Zimbabwe; Email: ishiemugari@gmail.com
}

\section{Munyaradzi Tundu}

Student: Department of Intelligence and Security Studies, Bindura University of Science Education, Bindura, Zimbabwe

\section{Doi:10.5901/mjss.2015.v6n5s1p323}

\section{Abstract}

\begin{abstract}
Vigilantism, a phenomenon which is premised on a model of retributive instant justice, negatively affects the moral social fabric. Its pervasiveness traverses local communities and beyond, and involves diverse methods by diverse perpetrators. Prattern (2008) posits that vigilantism, with its symptomatic culture of violence, has the propensity to unseat duly elected governments. Surprisingly, in Zimbabwe, little attention has been given to the threat posed by vigilante activity, yet it is a brutal indictment on policing as well as on the criminal justice system, (Haefele, 2008). This study, a descriptive survey in which 350 participants were invited to participate, investigated the causes of vigilantism in Mbare high density suburb, Harare. The study found that, public belief in a just world, police corruption, public mistrust in the judicial system, political factors, and challenges posed by a downward economic trajectory were some of the contributory causes of vigilantism in Mbare. Recommendations were that: police and the judiciary need to address their real and practical failings, including effectively dealing with allegations of corruption within their ranks; Government must support policing initiatives as well as improve infrastructure; Vigilantism needs to be prioritized and tackled as a form of crime; and a culture of violence must be delegitimized through inculcating a human rights culture in the citizens.
\end{abstract}

Keywords: Vigilantism, crime, violence

\section{Introduction}

On 13 March 1985, Robert Gabriel Mugabe, the then Prime Minister of the Republic of Zimbabwe remarked '......we must underscore the point that effective policing must derive and flourish from the goodwill and co-operation with the whole community from whom any Police force must derive its legitimacy' (Police Outpost, September 2011). This statement was made against the background that prior to independence, the British South Africa Police (BSAP) had pursued a policing philosophy of policing by coercion. The police was used as the instrument of the state which reflected colonial interests at the expense of the masses and was viewed as a public enemy. The dawn of independence in 1980 left a deep chasm between the police force and the people of Zimbabwe, who had shown each other outright hostility for decades before independence. Henceforth, the Prime Minister's 1985 statement became a bedrock through which the Zimbabwe Republic police would pursue various policing initiatives in order to foster wider public participation.

Amongst various policing initiatives that the police undertook, is the famous launch of the Police Service Charter in 1995, which was aimed at providing the public with the minimum standards that they should expect from the police in terms of service delivery. The ZRP also pursued other policing initiatives with the intention of educating the masses so that they could identify with the objectives and functions of the police as their own, where the police would also in turn, feel the people's needs and aspirations as their own. The role of Community Relations officers became redefined and other initiatives such as the Neighbourhood Watch Scheme, Crime Committees, Business against Crime and Home Officer Schemes were established in order to improve crime management and awareness. Despite all these policing initiatives, acts of vigilantism in Mbare continue to be witnessed, and hardly a month passes by without cases of vigilantism being perpetrated (The Herald, 5 May 2011). Thus, the study sought to investigate why vigilante activities 
continued to be perpetrated from January 2010 to December 2012, despite police efforts and initiatives in policing crime.

\subsection{Statement of the Problem}

There is a social contract that exists between the police and the community for effective policing. The general public ordinarily feels safe and secure when the police professionally execute its constitutional mandate of preserving the internal peace, general maintenance of law and order, protecting life and property, as well as arresting offenders. The police force also thrives on the maximum co-operation from the public for meaningful and effective policing. The Commissioner General of Police has often been quoted by Media Houses portraying the Zimbabwe Republic Police as one of the best in the Southern Africa Region (Ncube, Police Outpost, August 2012). In addition, the Zimbabwe Republic Police have crafted apt crime management tools as well as community policing strategies in order to fight crime as well as roping in more community involvement, thus bolstering both public confidence and support. Despite these various policing initiatives for crime awareness and management in Mbare area of policing, the media houses have been awash with reports of instant justice being meted out on perceived perpetrators of vice (Boriwondo, Herald, 5 May, 2011). Henceforth, the study sought to investigate the causes of vigilante activities in Mbare despite police efforts to contain crime between January 2010 and December 2012.

\subsection{Objectives of the Study}

The study was guided by the following objectives:

$>$ To identify types, nature, and prevalence of crime in Mbare.

$>$ To explore the causes of vigilantism in Mbare.

$>$ To suggest possible solutions and recommendations on the best practices to deal with vigilantism.

\section{Literature Review}

\subsection{Theoretical conception}

\subsubsection{Wilson and Kelling' Broken Windows Theory}

Wilson and Kelling (1982) propound Broken Windows as a criminological theory of the norm-setting and signaling effect of urban disorder, crime and vandalism. Broken Windows theory profoundly explains why certain crimes are committed in the communities, as an expression of anti-social behavior. The theory states that maintaining and monitoring urban environments in a well-ordered condition, may stop further vandalism and escalation of petty crimes into more serious crime, leading to crime prevalence. Wilson and Kelling (ibid) suggest that a successful strategy for preventing vandalism and crime degeneration is to fix the problems when they are small. The theory presupposes that most old urban townships that are not well maintained struggle to contain, among other vices, graffiti, alongside crimes such as theft, robberies, rape, and burglary.

Wilson and Kelling theory is widely supported by Newman (1999) who affirmatively states that, although work done by the police is crucial towards crime prevention, thus reducing crime prevalence, the presence of the police authority is just not enough for a safe and crime-free city. Newman's (ibid) Defensible Space theory suggests that people in the community also need to lend a hand towards crime prevention where he proposes that people will take care of and protect their own spaces in order to arrest crime prevalence in the neighbourhood. Newman (ibid) further argues that people should feel a sense of ownership and responsibility towards their area. The reason why broken windows and acts of vandalism are still prevalent is because communities simply do not seem to care about the damage. Once the community has not taken care of their locality, crimes such as burglary and theft are easily committed without restraint (Newman, 1999).

Newman (ibid) also suggests that a community ravaged by crime prevalence such as theft, rape, and burglary must establish informal social controls that can be an effective strategy to reduce unruly behaviour as well as crime in the community. Newman (1999) further exalts the role of informal social control, exercised through everyday relationships and institutions as more effective than legal sanctions, in order to effectively deal with crime and its prevalence. Finally, Newman (ibid) argues that, through informal social control methods, proactive citizens demonstrate a "get tough" attitude, and express a sense that disorderly conduct and crime will not be tolerated.

Burton's (2003) research findings in Meadowlands, South Africa reveal that Meadowlands is one of Soweto's 
oldest suburbs created in 1958 as a direct result of the forced removal policy of the apartheid state, which has witnessed a legacy of political turbulence unique to the township areas of South Africa. It now, however, bears evidence to a different type of violence; vigilante violence played out in the form of criminal activity to which the inhabitants of the area still fall victim.

Contrary to popular perception, crime in South Africa's Meadowlands is not committed by foreigners or by people from other parts of Soweto or Johannesburg (Burton, 2003). Rather, victims and non-victims alike believe that crimes are committed by people living in Meadowlands - largely young people and the unemployed. Burton (ibid) affirms that Meadowlands residents are daily exposed to household crimes such as theft of car, burglary, robbery, hijacking, assault and murder. Resultantly, the continuous exposure of Meadowlands citizens to the threat of crime and continued failure by the police to deal with it, as well as the persistent alarming rate of poor police visibility, has led the residents to turn to vigilantism as a form of punishment on purported offenders. This study sought to find out if Burton's research findings on the prevalence of crime in Soweto's Meadowlands and the subsequent resorting of its citizens to vigilante activities were applicable to Zimbabwe's Mbare scenario.

\subsubsection{Vigilantism and Political theory}

In "Vigilantism and Political Theory", Stettner (2009) turns first to the classic social contractarians, more specifically John Locke, who has a unique view of the state of nature and why some people form vigilante groups. Stettner quotes from the Second Treatise, in which Locke claims that, in the state of nature, individuals have the right to pursue justice, having equivalent "executive power" to punish crimes against the laws of nature. Sttetner further argues that, some civil governments, in an attempt to perpetuate their rule, may use vigilante groups as a form of oppression. However, Stettner (2009) concedes to the objection that it is unreasonable for men to be judges in their own cases, that self-love will make men partial to themselves and to their friends. On the other side, ill nature, passion and revenge will carry them too far in punishing others; hence nothing but confusion and disorder will follow.

Secondly, Sttetner borrows from the Marxist view point on vigilante political theory that normatively, any attempt to preserve the status quo of a civil government is of no ethical value, as it is futile (Sttetner, 2009). History, for the Marxist, inevitably witnesses the destruction of all established classes until the proletariat is finally triumphant. Thus any vigilante activity is simply a failure to accept the inevitable pattern of change. The Political Theory has been applied with approval in the removal of some civil governments, particularly in West African countries, where the powerful have often turned to vigilante groups as a means to ascend to power (Prattern, 2008). This was contrasted with the research undertaken, to see whether Prattern's (ibid) theory could be contextualized to the location under study.

\subsubsection{Anomie Vigilante}

Durkheim (1994) famously presented the concept of anomie or "normlessness" as the condition when society is disturbed by some painful or by beneficent but abrupt transitions, where it is momentarily incapable of exercising social influence. Anomie essentially refers to a social condition in which a prevailing system of norms begins to break down. "Abrupt transitions" are social exigencies - revolution, war, economic recession leading to unparalleled social vices such as theft, assault, arson, and social change - that affect confidence in the stability of existing social norms and therefore produce a disparity between value expectations and value capabilities.

Under conditions of anomie, individuals experience psychological dissatisfaction (Durkheim, 1994). With philosophical, economic, psychological, and sociological treatments of norm-violating acts and social disorder, people can easily resort to vigilante activities as a way of expressing their frustrations on perceived life challenges. Vigilante activity becomes a crisis phenomenon that encompasses perceived social dysfunctions brought about by norm-violating exigencies that, as public wrongs, produce a psychological reaction throughout society that requires rectification. The period under study has been widely regarded as a transitional period where political foes formed a government of national unity, which came after a regrettable period of political instability and deep economic recession. However, the same period has actually been regarded by political analysts as a stable one that saw the political environment and the economy stabilizing (Financial Gazzette, Thursday 11 March, 2010). The concept of Anomie vigilante, which clearly presupposes the exposure of a society to abrupt social exigencies which are mostly negative, was weighed in to find out its relevance, in as far as the emergence of Vigilantism in Mbare was concerned. 


\subsubsection{Adelstein's Just World Theory}

Adelstein (2004) states that vigilante activity is precipitated by what he terms a belief in a just world. Just World theory is an important theory on the formation of justice perception. The theory proposes that people's reactions to crime victimization can be understood as attempts to preserve a belief in a just world, the belief that the world is a place where individuals get what they deserve, and deserve what they get. The theory further proposes that 'good things happen to good people, and bad things happen to bad people'. Adelstein (supra) further suggests that people are keen on protecting their belief in a just world, and when confronted with an injustice, they will experience an aversive state. Eventually, the people will try to reduce this unpleasant state by using strategies to protect their belief in a just world. Adelstein (supra) further argues that such strategies include denial of the injustice, or attempt to restore the justice by punishing the offender. Thus, Adelstein, (supra) asserts that public reactions which are often labeled as 'support for vigilantism' must be actually be interpreted as 'believe in just world reactions'. The research also established the relevance and the applicability of Aldestein's Just World Theory, in explaining why vigilante activities cropped up in Mbare. In addition, the research also established whether there were isolated reasons that led to the emergence of vigilante activities in Mbare, other than a mere belief in a just world.

\subsubsection{Rosenbaum and Sederberg's Social Group Control Vigilantism Theory}

Rosenbaum and Sederberg (2010) propound that Social-group-control vigilantism is an example of pure expressive norm enforcement; where social group-control vigilance committees often organize along communal or "primordial" characteristics such as race, religion and culture. San Francisco Committee of 1856 is as an example of social-group vigilantism, highlighted by the dichotomy of political and religious value systems between the Protestant (and often Republican) merchant vigilantes and lower class Irish-Catholic Democrats. The goal of social-group-vigilantes is to intimidate or violently oppress upwardly-mobile groups vying for increased representation in or control of the state apparatus. Rosenbaum and Sederberg (2010) further state that racial social-group-control also targets the 'immoral' and low elements of society. It is clear from the theory that vigilantism may emerge as a result of collective effort by a group of people who share the same religious, cultural or social belief systems, who see the need to gang up against perceived elements of the society who threaten their shared values. In investigating the causes of vigilantism in Mbare, this study established whether the suppositions of Rosenbaum and Serderberg's theory have any relevance to the Zimbabwean context.

\subsubsection{Police methods in dealing with Crime and Vigilantism}

Sansfacon (2000) postulates that crime prevention involves strategies, and measures that seek to reduce the risk of crimes from occurring and their potential harmful effects on individuals and society, including fear of crime, by intervening to influence their multiple causes. Crime prevention has traditionally been seen as the responsibility of the police or as stemming from the deterrence of the law or repression of offenders. Where the public feels that the police are not employing adequate crime prevention strategies, confidence is eroded, leading to a frosty relationship between the custodians of the law and the policed (Sansfacon, ibid). Such an environment creates a bedrock for fomenting social instability, and the society can easily degenerate into lawlessness. Views advanced by Sansfacon (ibid) were tested against the findings of this research, which sought to establish whether there was a link between the penal system, the citizens' lack of confidence in law enforcement and their subsequent resorting to vigilante action as a method of preventing crime.

Redo (2008) refers to the 1995 and 2002 United Nations Guidelines on crime prevention and underscores the fact that there is much broader role by the government at all levels to establish proactive rather than reactive strategies for preventing and reducing crime, thereby reducing the opportunity for vigilantism. Housing, health, job creation, social services, and environmental services, among other initiatives can make a significant difference to crime levels. Sansfacon (2000) concurs with Redo (ibid) and further asserts that fundamental to the development of crime prevention strategies is the existence of the rule of law, a viable criminal justice, recognition of human rights and the use of policies that are inclusive of all sectors and groups of the society. This study established whether the recommendations cited by the various authors on crime prevention were also relevant, in the context of policing crime in Mbare.

Redo (2008) affirms that situational crime prevention methods reduce the opportunity for crime and victimization, through improved urban renewal and environmental design such as appropriate housing and surveillance. Giddens (2004) concurs with Redo (ibid) and further asserts that target hardening and surveillance system has been a popular 
approach to manage the risk of crime. Such techniques are often favored by policy makers because they are relatively simple to introduce, alongside other policing techniques as they assure citizens by giving them the impression that decisive action against crime is being taken. However, Gopge (2003) differs with Giddens (ibid) and argues that such techniques do not engage with the underlying causes of crime such as social inequalities, unemployment, and poverty. Their greatest success lies in protecting certain segments of the population against crime, and displacing delinquency into other realms.

Whilst the above researchers predominantly dealt with crime prevention strategies in general, Gopge (2003) researched on methods of dealing with vigilantism in particular and asserts that the South African Police implemented a raft of measures in the Western Cape. These include establishing Community Safety Measures to establish a vehicle for facilitating the implementation of a multi-agency crime prevention approach at local level, training police officers and citizens alike on conflict resolution, with a view of establishing a conflict intervention team at station, and at local level. Community training on the Criminal Justice System and on Human Rights, evaluation processes, and development and communication methods in Khayelitsha were introduced as crime and vigilante combating strategies, and community participation was effectively sought.

Gopge's (ibid) research findings in the Western Cape further reveal that the government felt that there was need to educate communities on the work of the police and the role of the criminal justice system, need to address police corruption, as well as improvement on service delivery. The government also acknowledged that it has a duty to look at job creation, better co-operation between justice, the police and the community, improve rehabilitation programs in jails, introducing severe penalties for serious crimes and finally the need for parents to be more involved in children's activities, if acts of vigilantes, and crime challenges are to be effectively dealt with. This research evaluated the current situation obtaining in Mbare to establish what the government has done, to deal with crime and the challenges brought about by acts of vigilantism.

\subsection{Empirical Literature Review}

According to American Law Review (2011), classic vigilantes were members of an organized committee, established members of the community who proceeded with definite goals (not with the intention of random violence) and acted as the last resort because of failure of the established law system. Vigilante justice has been carried out for centuries but it gained a great deal of recognition in the United States in 1800 with Vigilante Committees which ostensibly fought crime but actually persecuted immigrants and blacks. They conducted public lynching and other forms of punishment in an attempt to frighten members of the minority out of town. In the American West, vigilante justice was also used as a tool to dispatch political rivals and anyone who owned substantial land and mineral claims was at the risk of being executed by a vigilante mob under the direction of an acquisitive enemy. This study endeavored to investigate whether vigilantism in Mbare had been necessitated by the politically powerful, as a tool to get rid of political rivals, as in the case of classic vigilantes.

Rosenbaum and Sederberg's (2010) research findings in Amsterdam, Netherlands revealed that vigilantism surfaced predominantly in situations of effecting citizen arrest. In 2002, Amsterdam police struggled to deal with this problem, the highlight of which was the shooting of a shoplifter by two supermarket employees, after they had already arrested and handcuffed him. The two employees were arraigned before the court for murder, and the prosecution felt that this was an unjustified violence.

Minnaar (2001) analyses the causes, extend and forms of vigilante violence in South Africa, across a time frame that starts just before the political transition, through the period characterized by political transformation, reconciliation and the brokered peace of the post 1994 era. Minnaar (ibid) postulates that vigilantism in South Africa's Western Cape for example, is a brutal indictment of the whole criminal justice system, and an expression of its failure and the inadequacies of policing. In the post-1994 era, vigilantism has been predominantly defined by recourse to 'fighting crime'. Minnaar's (ibid) research project explored the relationship between crime-fighting vigilantism and the formal criminal justice system. Minnaar (ibid) discovered that vigilante violence is frequently justified as 'filling a policing gap' due to police inefficiency, corruption and compliance with criminals; practical failings in the criminal justice system. Gopge (2003) concurs with Minnaar (2001) but further stresses that the danger of vigilantism is that, not only does it lead to an increase in the overall level of crime; it also influences on how government responds to crime generally and most importantly, it undermines the rule of law.

Minnaar's (2001) research findings in Western Cape reveal that vigilante groups like People against Gangsterism and Drugs (PAGAD) and Mapogo-A-Mathamaga have, to a greater extent, contributed to a rise in gang related violence and assault cases. Minnaar, (ibid) further highlights that, crime statistics in 1999/2000 for murder, attempted murder, 
robbery with aggravated circumstances, theft, public violence and common assault were on the increase. Most assault cases were predominantly domestic related, some of which were orchestrated as a vigilante response to domestic violence committed on perceived innocent women and children (Minnaar, ibid). Thus, most vigilante activities mostly occurred as a response to the above mentioned crimes. According to Gopge's (ibid) research findings in Western Cape's Khayelitsha Township, there has been a steady increase of vigilante activities with an average of seven cases being reported every month.

Gopge's (2003) research findings in the Western Cape identify that political interference, leniency of the constitution, poor police visibility, high rate of unemployment, poverty, alcohol abuse as well as lack of trust in the prosecution system as contributory factors in the emergence of vigilante activities. Furthermore, the community's perceptions of poor or no service delivery by the service providers, lack of resources such as proper housing, transport, education, health, lack of trust in the police due to political history, corruption, lack of understanding and trust in the functions of the judicial system, insignificant witness protection, lengthy court trials and lack of transparency in the parole granting process also contributed to the emergence and rise of vigilantism in the Western Cape, (Gopge, 2003). It was the intention of the research to find out whether the empirical studies established by other researchers cited above had any connection to what might have led to the emergence of vigilantism in Mbare.

\section{Research Methodology}

A Descriptive Survey design was used in carrying out this research. Out of a target population of 3500 households in Mbare and 55 police officers stationed at Mbare Police, a sample that comprised of 350 home owners and 10 police officers was selected to take part in the study using simple random sampling and stratified random sampling techniques. The questionnaire, individual interview using an interview guide and focused group discussion using a focused group discussion guide, were the key data collection techniques. Quantitative data was analysed using Software Package for Social Sciences (SPSS) whilst qualitative data was analysed using summative content analysis.

\section{Research Findings}

\subsection{Prevalent crimes in Mbare}

The majority of the respondents indicated unlawful entry and theft, theft, and assault cases as the most prevalent crimes, with a percentage rating of $73.8,80.6$, and $80.9 \%$ respectively. Unlawful entry and theft obtained a mean statistic of 1.28 \pm 0.494 , indicating that respondents overall, felt that the suburb had a high prevalence of Unlawful entry and theft cases. The same applies to Theft, which obtained a mean statistic of $1.21 \pm 0.459$, which is a clear indication that theft is also one of the most prevalent crimes. Assault was also not an exception, with a mean statistic of $1.31 \pm 0,676$. Views obtained from the sample are presented on Table 1.

Table 1: Descriptive statistics of most prevalent crimes in Mbare $(\mathrm{N}=340)$

\begin{tabular}{|l|c|c|c|c|c|c|c|}
\hline \multirow{3}{*}{ Crime } & Very High & High & Moderate & Low & Very low & \multirow{2}{*}{ Mean } & \multirow{2}{*}{ SD } \\
\cline { 2 - 9 } & $\mathbf{1}$ & $\mathbf{2}$ & $\mathbf{3}$ & $\mathbf{4}$ & $\mathbf{5}$ & & \\
\cline { 2 - 9 } & $\mathbf{\%}$ & $\%$ & $\%$ & $\%$ & $\%$ & & \\
\hline Unlawful entry and Theft & 73.8 & 24.1 & 2.1 & 0 & 0 & 1.28 & 0.494 \\
\hline Theft & 80.6 & 17.4 & 2.1 & 0 & 0 & 1.21 & 0.459 \\
\hline Assault & 80.9 & 7.1 & 12.1 & 0 & 0 & 1.31 & 0.676 \\
\hline Rape & 3.2 & 5.3 & 23.8 & 61.8 & 5.9 & 3.62 & 0.810 \\
\hline Indecent Assault & 22.1 & 7.4 & 44.1 & 23.2 & 3.2 & 2.78 & 1.129 \\
\hline Malicious Damage to property & 1.8 & 18.8 & 40 & 30.6 & 8.8 & 3.26 & 0.924 \\
\hline
\end{tabular}

Source: Primary data

It is quite evident from the data collected that Theft, Assault and Unlawful Entry and Theft were the most prevalent crimes in Mbare. These findings concur with Gopge's (2003) findings in South Africa, Khayelitsha suburb, Western Cape, where cases of Assault, Unlawful entry and Theft were found to be the predominant crimes in the township. 


\subsubsection{Discussion on the most prevalent crimes in Mbare}

The researcher sought to find out the most prevalent crimes in Mbare and to establish whether these had a nexus to the emergence of vigilante activity, as had been revealed by the empirical literature review, particularly in the case of Classic American Vigilantes (American Law Review 2011), as well as Gary (2008)'s research findings in the sprawling favelas of Rio de Janeiro. The following stood out as the most prevalent crimes in Mbare;

Assault

Mbare Police Station grapples to contain assault cases as reflected by the views gathered from the respondents. At the time of carrying out this research, statistics showed that it was the most committed offence in Mbare. Durkheim's (1994) concept of anomie explains this phenomenon as he asserts that psychological dissatisfaction in existing social and economic conditions leads to a breakdown in social norms, and subsequently social exigencies such as assault are bound to be committed. Minnaar's (2001) research findings reveal a trajectory similar to that of Mbare, where vigilante activities in the Western Cape were perpetrated against the background of rising assault cases.

Unlawful Entry and Theft

The majority of the responses revealed that most residents had been victims of unlawful entry and theft. Even responses solicited from police participants highlighted that the station battled with reports of break-in into houses nearly thrice a week, and the crime is the major reason why the crime register index is on the high. Gary's (2008) research findings in Rio de Janeiro depict the responses gotten from Mbare, where security concerns, high population density and inadequate housing became convenient opportunities for thieves to pounce on innocent victims leading the national police to struggle in containing the rampaging crime. Resultantly, this led to the poor citizens losing confidence in them, and they resorted to vigilantism.

Theft

Respondents also indicated that theft in the suburb was rampant. The outcome of Gary's (2008) studies in Rio de Janeiro's favelas revealed that Rio police struggled to contain soaring cases of theft in the favelas, primarily due to high population density and poor security on housing. Respondents' views on theft as a prevalent crime concur with propositions of Wilson and Kelling (1982) Broken Windows theory where there is a signaling effect of urban disorder, crime such as theft and vandalism are inevitable. Poor housing, poor street lighting, insecurity and non- repairing of infrastructure in Mbare led to the escalation of petty theft crimes into more serious crime, leading to crime prevalence.

\subsection{Respondents' knowledge about vigilantism}

An overwhelming majority (75\%) indicated that they were quite aware of vigilantism. As depicted by Table 2, only $11.5 \%$ had virtually no knowledge on vigilantism.

Table 2: Respondents' knowledge about vigilantism

\begin{tabular}{|l|c|c|}
\hline Response & Frequency & Percentage \\
\hline Quite aware & 255 & $75 \%$ \\
\hline Rough idea & 46 & $13.5 \%$ \\
\hline Not aware & 39 & $11.5 \%$ \\
\hline Total & 340 & $100 \%$ \\
\hline
\end{tabular}

\subsection{Perception of vigilantism as a practice}

Slightly below half (47\%) of the total respondents viewed vigilantism as a bad practice. Interestingly, $41 \%$ of the total respondents viewed vigilantism as a bad practice (Table 3).

Table 3: Respondents' views on vigilantism as a practice

\begin{tabular}{|l|c|c|}
\hline Response & Frequency & Percentage \\
\hline Bad practice & 160 & $47 \%$ \\
\hline Good practice & 140 & $41 \%$ \\
\hline No comment & 40 & $12 \%$ \\
\hline Total & 340 & $100 \%$ \\
\hline
\end{tabular}


Whilst statistics obtained slightly depict vigilantism as a bad practice, Gopge (2003) effectively points out that that the danger of vigilantism is it undermines the rule of law. However, Prattern's (2008) research findings in post-colonial Nigeria justify vigilante activity. Prattern (supra) further argues that vigilantism derives local legitimacy from narratives of contested rights, as a legitimate means and every day practice and a justified barometer on matters of governmentality.

\subsection{Causes of vigilantism}

Table 4. Descriptive statistics of the causes of Vigilantism in Mbare $(N=340)$

\begin{tabular}{|c|c|c|c|c|c|c|c|}
\hline \multirow{3}{*}{ Vigilante Activity (causes) / (factors) } & Strongly Agree & Agree & Neutral & Disagree & Strongly Disagree & \multirow{3}{*}{ Mean } & \multirow{2}{*}{ SD } \\
\hline & 1 & 2 & 3 & 4 & 5 & & \\
\hline & $\%$ & $\%$ & $\%$ & $\%$ & $\%$ & & \\
\hline Low police visibility & 72.4 & 21.3 & 0 & 2.8 & 0 & 1.31 & 0.625 \\
\hline Police Corruption & 73.5 & 20.6 & 0 & 2.9 & 2.9 & 1.41 & 0.881 \\
\hline Mistrust in the judiciary system & 72.1 & 23.5 & 0 & 3.5 & 0.9 & 1.38 & 0.744 \\
\hline Poorly equipped police force & 16.2 & 16.2 & 0 & 62.9 & 4.7 & 3.24 & 1.255 \\
\hline Inadequate Laws to address societal issues & 32.4 & 26.5 & 29.4 & 8.8 & 2.9 & 2.22 & 1.088 \\
\hline Political factor & 77.9 & 19.5 & 1.2 & 1.5 & 0 & 1.26 & 0.554 \\
\hline Belief for a Just world & 85.3 & 12.7 & 2.1 & 0 & 0 & 1.17 & 0.426 \\
\hline Reaction to economic challenges & 46.6 & 50.7 & 2.7 & & 0 & 1.56 & 0.58 \\
\hline
\end{tabular}

Source: Primary data

Table 4.6 shows that $85.3 \%$ of the respondents concurred that vigilante activities were largely committed as a result of a strong belief for a just world; political factor (77.9\%); police corruption (73.5\%) low police visibility (72.4\%), and a general mistrust in the criminal justice system (72.1\%). The 'belief for a just world' had a mean statistic of $1.17 \pm 0.426$, political factor, $1.26 \pm 0.625$, police corruption, $1.41 \pm 0.881$, low police visibility, $1.31 \pm 0.625$, whilst mistrust in the criminal justice system had a mean statistic of $1.38 \pm 0.744$. This indicates that the majority of the respondents agreed that the above mentioned variables were the major causes of vigilantism. Respondents' views can be figuratively shown as below:

\subsubsection{Belief in a Just World}

Views obtained from the majority of the respondents clearly indicated that most of the participants strongly agreed that vigilante activities are committed as a response to the desire to maintain a just environment, free from the vice of crime. An insignificant Standard Deviation of 0.426 buttresses the fact that the majority of the respondents justified vigilantism on lawbreakers so as to get rid of criminal tendencies in the society. This concurs with Adelstein (2004)'s Just World theory that states that vigilante activity is precipitated by a belief in a just world where people's reactions to crime victimization and vigilante action can be understood as attempts to preserve a belief in a just world. Henceforth, every criminal element in the society gets what he or she deserves.

\subsubsection{Political factor}

The Political factor obtained a Mean Statistic of $1.26 \pm$ an insignificant Standard deviation of 0.554 from the sample, indicating that the majority of the respondents considered political influence as a major contributing factor that fuelled vigilantism in Mbare. Data gathered from participants also pointed out that there has been a significant political hand in the criminal justice system, and the majority felt that the criminal justice system had been heavily compromised, leaving the residents with no choice but to resort to vigilante activities as a way of addressing crime bedeviling the society. On the other hand, the political hand had also been active in fuelling vigilante activities, as various political players used the predominantly unemployed youths to form vigilante groups such as Chipangano, to coerce people in Mbare to vote for them. Prattern (2008) describes this phenomenon in Nigeria where he argues that that contemporary vigilantism has been at the forefront of contests over state authority, and that political leadership has often used vigilante groups as a machinery to entrench state rule as well as state authority. 


\subsubsection{Police corruption}

The responses obtained from the sample highlighted corruption in the police force as one of the reasons why the general public resorted to vigilante activities than using the available legal framework to address issues of criminality. Police corruption obtained a Mean statistic of $1.41 \pm 0.881$, indicating that the majority of the respondents agreed that corrupt tendencies in the force left the residents reluctant to report to them, in an event of crime occurrence, henceforth, the public had to resort to meting out instant justice. The perceptions of the respondents resonate well with Gopge's (2003) research findings in the Western Cape who asserts the community's perceptions of rampant corruption within the rank and file of South African Police also contributed to the emergence and rise of vigilantism in the Western Cape.

\subsubsection{Low Police Visibility}

Low police visibility in Mbare area of policing was also cited as a contributory factor to the emergence of vigilantism, as reflected by the Mean statistic of $1.31 \pm 0.625$ obtained from the sample. Seventy two (72\%) percent of the respondents showed that low police visibility contributed to the emergence of vigilantism. In fact, combined views from both the public and police officers unanimously revealed that police presence in the neighborhood was rare although the reasons for this state of affairs were divergent. As for the public, the popular opinion was that the police had evidently abdicated on its constitutional mandate of policing, in pursuit of self aggrandizement agenda, while the police bemoaned lack of human and material resources as the major cause why they could not saturate their policing area for effectiveness. The responses on poor police visibility echo with Gopge's (2003) and Burton's (2003) research findings in Khayelitsha and Meadowlands respectively, that continued absence of the police in the neighborhood contributed significantly to the emergence and rise of vigilantism in the two suburbs where residents resorted to taking the law into their hands.

\subsubsection{Mistrust in the Judicial System}

Closely linked to police corruption and the political factor was the respondents' revelation that they longer trusted the competency of the judicial system as reflected by the Mean statistic of $1.38 \pm 0.744$. Seventy two percent $(72 \%)$ of the responses that the researcher received from the participants pointed out that the courts' reputation had been largely dented with accusations of corruption. Minnaar (2001) argues that more often, citizens are not aware of the criminal justice processes and procedures, to an extent that they often mistake matters such as granting of bail to suspects as releasing of suspects. Indeed, most of the responses obtained from interviews indicated that the citizens were not happy with the judicial process, especially lengthy trial proceedings, granting of bail and light sentencing. No wonder why some resort to vigilante activity as an option. Gopge (2003) cites this scenario as one of the factors that led to the emergence of vigilantism in Western Cape's Khayelitsha suburb when the citizens felt that many cases were being withdrawn on flimsy grounds like inadequacy of evidence only for perpetrators to return to their criminal activities. Due to inability to efficiently prosecute criminals, the people in Khayelitsha had no option but to take matters into their own hands.

\subsubsection{Reaction to economic challenges}

Reaction or response to challenges of a downstream economy were not as dominant as the factors cited above, but combined views (96\%) of those who concurred that they strongly agreed and those who simply agreed that economic collapse led to emergence of vigilantism had a mean statistic of $1.56 \pm 0.58$, a range adequate to assert that economic challenges had indeed, a direct influence on vigilante activities in Mbare. Haefele's (2013) contribution on Sociological theory on the causes of vigilantism highlights that dissatisfaction with social or economical issues by the society gives rise to the incidences of vigilantism. Economic challenges, usually associated with high cost of living and high unemployment lead to mass frustrations, and people become distraught, to an extent that any situation (for example, criminal activity), that threatens their precarious position is met with abrupt reaction such as vigilante activity.

However, divergent to the causes cited above, are the findings of Prattern (2008) in Nigeria, who, apart from political interference, asserts that contemporary Nigerian vigilantism involves a range of local and global dynamics beyond informal justice. Instead, Prattern (ibid) argues; Nigerian vigilantes are not only explained as a response to crime and a vacuum left by the state; but also that the religious factor predominantly played a major role in perpetrating vigilante activities particularly in the Southern regions of Nigeria. Judging from the responses solicited from the people, it appears that religious factor is too remote as to influence the emergence of vigilante activities in the Zimbabwean context.

Divergent to the causes of vigilantism obtained from the study is also Rosenbaum and Serderberg's (2010) 
findings, who perceived vigilante activities of San Francisco Committee of 1856 as the dichotomy of political and religious value systems whose ultimate intent was to intimidate or violently oppress upwardly-mobile groups who were vying for increased representation in or control of the state apparatus. The reverse is true for Mbare political vigilantes where those in political leadership actually mobilized the youths as coercive instruments to help them gain allegiance from the citizens for political aggrandizement.

\section{Conclusions}

Judging from the primary data gathered from the respondents, vigilantism is not a good practice, as the majority indicated, but in the absence of effective crime management by the police, it remains a justified option available to the citizens albeit with a dangerous possibility of pulling the society into the abyss of lawlessness. Collective effort must be harnessed, from the political will, the police and the general public so that the nation may be saved from this emerging phenomena, which has the potential to throw the nation into a state of utter lawlessness. Not only does the phenomenon have the potential to create a breeding ground for crime perpetuation, it has the potential to unseat duly elected governments. Whilst vigilante action has some positives of note, as advanced by Newman's (1999) Defensible Space theory, that suggests that people in the community also need to lend a hand towards crime prevention through establishing informal social controls in order to arrest crime prevalence, citizens' non observance of the legal channels can actually lead the society to be more susceptible to criminal deviance.

\section{Recommendations}

A number of practical and interdependent initiatives suggest themselves from the research findings which can assist the ZRP in dealing with the problem of vigilantism. It is evident, from the findings that the majority of the citizens expressed mistrust in the police, and other criminal justice, and the citizens resorted to vigilantism as an alternative. From the views gathered from the respondents, the researcher opines that the following must be put in place in order to curb the vigilante phenomenon:

\subsection{Addressing the police challenges in crime management}

Vigilante activities have been justified as a response by the police's failure to manage and curb crime prevalence in Mbare. The respondents' views revealed that the police had abdicated on its policing mandate, coupled with allegations of police inaction and incompetence, corruption, and complicity with alleged perpetrators of crime. Mistrust generated from this sad state of affairs did not help in saving the battered image. The police as an organization need to acknowledge its shortcomings, and deal with the root causes. It must be seen 'walking the talk', with regards to allegations of corruption. Only when it has taken some measures to rebuild a positive image, will the nation witness the restoration of public confidence in policing. If allegations of incompetence are anything to go by, then the police must review its training curriculum, as well as considering refresher courses to keep the organization abreast with the changing criminal trends as well as the sophistication of criminals.

The police, as an organization really need to make use of its community policing initiatives as a building block to win back public confidence. Much has been talked about the Home Officer schemes and use of suggestion boxes and hotlines, but the mere fact that some respondents depicted total ignorance on some of the methods at police disposal in crime prevention reflects that these initiatives are not fully utilized. Low police visibility does not work in the police' favour and the earlier the organization realizes this, the better for its effectiveness. Whilst the police may cite budgetary constraints as a reason for low police visibility, there is need to revitalize its Neighbourhood Watch Scheme, which is a low cost but very effective method of crime prevention.

\subsection{Addressing the real challenges of the judicial system}

The judiciary, according to the research findings, also contributed to the emergence of vigilantism. It is arguable the respondents might have misperceptions on how the judiciary system functions in terms of trial proceedings, but allegations of corruption, complicity and collusion with alleged offenders do not put the judicial officers in good light. These allegations must be directly tackled and the Judicial Service Commission as well as the Anti Corruption Commission of Zimbabwe must be vigilant in effectively dealing with the bad apples within the realm of the judicial service so that it will be able to gain public credibility and trust. However, the citizens also need to be educated on how the 
judicial system functions because some of the views obtained reveal that there is misconception on how the judicial system functions.

\subsection{Criminalising vigilantism}

It is not enough to simply target the police and the judicial systems' practical failures as the only focal points that need to be addressed. Vigilantism is just more than mistrust. True, in the context of this study respondents felt that they are justified in taking the law into their hands, and literally get away with it. Criminalising vigilantism will be a step in the right direction. All vigilante cases need to be appropriately recorded and carefully documented so that this may be brought to the attention of the legislative function. The longer the nation continues to tolerate vigilante violence, without prosecuting vigilantes, the more the system embraces a culture of impunity on vigilantism. Once vigilantism has been criminalized, alongside fast-tracking vigilante specific cases, there will also be a need to protect witnesses, particularly those who will testify in politically motivated and related vigilante violence.

\subsection{The role of the Government}

Without government support, in terms of funding and providing much needed resources, policing crime and vigilantism in particular remains futile. Minnaar (2001) states that the South African government for example, realized the need to have national co-ordination and a cohesive, systematic approach so that the problem of vigilantism could be effectively dealt with. In Mbare for example, the police grapple to deal with crime prevalence due to the dilapidated housing structures, poor street lighting and an ever growing population density. The earlier the government addresses these issues, the better for effective policing.

\section{References}

Adelstein, R. (2004) Victims as Cost Barriers: Oxford University Press. Buffalo Criminal Law Review, 3 ( I), 2004.

Alderson, J. (2004) Policing and the Community. Heinnermann Educational Books, London.

American Law Review on Crime and Vigilantes: Belief for a Just World Vol 2 pg 3-7 MacMillan Press, 2011.

Babbie E.R. and Rubbin, S. (1996) Survey research methods, Belmont California, USA.

Bayley, M.D. (1985) Crime, Juvenile Delinquency and Criminal Justice. Juta Co,South Africa.

Borg, W.R. and Gall, M.D. (2001) Research Methods in Education. Croom Helm Limited, London.

Brown, T.J. (2009) Strain of Violence: A Decent Orderly Lynching. The Montana Vigilantes, University Press, Oklahoma.

Bryman, A. (2003) Quantity and Quality in Social Research, Unwin Hyman, London.

Brink, D.E. (1996) Policing at the Crossroad (2nd Edition), Butterworths, United Kingdom.

Burton, P. (2003) Crime Prevention and Justice. University Press, Oxford.

Chingozha, M.P (2009) Contemporary Policing Module. Govt Printers, Harare.

Dooley, D.E. (2000) Social Research Methods (2nd Edition), Intervarsity Press, London.

Durkheim, E. (1994) The Division of Labour in Society. Free Press, New York.

Feltoe, G. (2005) Criminal Law Perspective, Juta Private Limited, Zimbabwe.

French, L.G. (2000) Vigilantism, Vigilante Justice and Victim self help [Online] Available on Http://www.faculty.nwc.edu.to.conner/300, [accessed on 16 October 2013].

Gary, L. (2008) BBC News on Vigilantism in Rio de Jenairo, Brazil. (08 March 2008).

Giddens, A. (2004) Sociology (4th Edition), Blackwell Publishing Inc, Cambridge

Glanz, L. (2001), Managing crime in the New South Africa, HSRC, Pretoria.

Gopge, M. (2003) Vigilantism: A crime or call for Justice? Cape Augus, vol 1, 2003 p 1-4.

Haefele, M. (2013). Emergence of Vigilantism in South Africa no.72 pg 1-9 [Online] Available on Http://www.iss.cozamonograph accessed on 16 October 2013.

Keizer, K. and Lindernberg, S. (2008) The Spreading of Disorder: Journal on Urban Environmental Planning and Design: Intervarsity Press, USA.

Koul, A.W. (2000) The Future of Policing. Sage Publications. Durban.

MacMillan, A.D. (1996) Management and Organisational Behaviour (7t Edition), Prentice Hall, UK.

Minnaar, A. (2001) The New Vigilantism in Post April 1994 South Africa.Crime Prevention or an Expression of Lawlessness? The Journal on the Institute of Human Rights and Criminal Justice Studies [May 2001, p 49].

Newman, O. (1999) Defensible Space: Crime Prevention through Urban Design, New York.

Mwanje, J.L. (2001) Issues in Social Science Research Methodology.OSSREA, Ethiopia.

Prattern, A. (2008) Introduction to the Politics of Protection: Perspective on Vigilantism in Nigeria, Africa. The Journal on the International African Institute Vol 78 no 1 pp 1-5. 
Radelt, B. and Carter, W. (1994) Contemporary Policing. Butterwoths, Pretoria.

Redo, S. (2008) Journal on the International Perspectives on Crime Prevention. Vol 1, Monchenglabach.

Rosenbaum, J.H and Sederberg, C.P. (2010) Vigilantism: An analysis of Established Violence in Vigilante Politics, Volume 2. University of Pennsylvania Press. Philadelphia.

Sansfacon, D. (2000) Investing wisely in Crime Prevention: International Experience.USA Bureau for Justice, Vol 2.

Schoefer, G. (1989) Social Research Methodology (3rd Edition) Prentice Hall. New Delhi.

Stettner, D.V. (2009) Vigilantism: A Political History of Political Power: Violence, Aggression, and Coercive Actions. American Psychological Association Vol 2, pp 1-12.

Tamura, Y. (2000) Community Policing In Perspective. Olga Printing, Tokyo.

The Zimbabwe Constitution (2013). Government Printers, Harare

The Police Outpost, August 2012, Police Printers, Harare

The Police Outpost, September 2011, Police Printers, Harare.

The Zimbabwe Republic Police Vision 2020, Police Printers, Harare..

The Zimbabwe Republic Police Standing Orders ( Vol 1), Police Printers, Harare.

The Zimbabwe Herald, 5 May 2011, Harare, Zimpapers Group Publishing Inc.

The Sunday Mail, 27 April 2008, Zimpapers Group Publishing Inc, Harare.

Trojanowicz, B. and Burcquerox, N. (1994), Crime and Justice, West Publishing, New York.

Uys, F. and Bason, R. (1991) The World on the Edge. University Press, Cambridge.

Wilson, J.Q and Kelling, G.L. (1982) Fixing Broken Windows: Restoring order and reducing crime in our communities: The Atlantic Journal, Vol 1

Zimbabwe Statistics Population census 2012, Government Printing Press, Harare.

Zvekic, U. (2000) Criminal Victimisation in Countries in Transition. UNICRI Publication, Rome. 